\title{
PENERAPAN MODEL PEMBELAJARAN PROBLEM POSING UNTUK MENINGKATKAN HASIL BELAJAR SISWA KELAS VIII A SMP NEGERI 2 KUTA TAHUN PELAJARAN 2017/2018.
}

\author{
Ni Ketut Dharmawati Geria Putri \\ SMP Negeri 2 Kuta \\ Email :putridharmawati@gmail.com
}

\begin{abstract}
ABSTRAK
Tujuan dari penelitian ini adalah meningkatkan hasil belajar IPA dengan menggunakan penerapan model pembelajaran problem posing pada Kelas VIIIA Semester Genap Tahun Pelajaran 2017/2018. Penelitian ini merupakam penelitian tindakan kelas, yang berlangsung dalam 2 siklus. Subjek penelitian adalah siswa kelas VIII A. Teknik pengumpulan data menggunakan penugasan dan tes. Data dianalisis dengan menggunakan analisis deskriptif dalam persentase dan analisis data kualiatif dengan mengacu pada Kreteria Ketuntasan Minimal $(\mathrm{KKM}=76)$ dan Ketuntasan Klasikal $(K K=85 \%)$ untuk mata pelajaran IPA kelas VIII SMP Negeri 2 Kuta tahun pelajaran 2017/2018. Hasil penelitian menunjukkan adanya peningkatan hasil belajar IPA, yaitu: nilai rata-rata hasil belajar dan ketuntasan klasikal sebelum tindakan adalah 71,1 dan 62\%. Pada siklus I rata-rata hasil belajar pada kompetensi pengetahuan adalah 76,4 dengan ketuntasan klasikal 68\%. Rata-rata hasil nelajar pada komentensi keterampilan adalah 77,5 dengan ketuntasan klasikal 62\%. Pada siklus II hasil belajar IPA pada kompetensi pengetahuan adalah 82,6 dengan ketentasan klasikal 94\%, hasil belajar pada kompetensi keterampilan 86,5 dengan ketuntasan 100\%. Berdasarkan hasil penelitian tersebut dapat disimpulkan bahwa penerapan model pembelajaran problem posing dapat meningkatkan hasil belajar IPA siswa kelas VIII A SMP Negeri 2 Kuta pada semester genap tahun pelajaran 2017/2018.
\end{abstract}

Kata Kunci: Model Pembelajaran Problem Posing dan Hasil Belajar

\section{ABSTRACT}

This study aims to: improve science learning outcomes through the application of problem posing learning models in Class VIII Semester 2017/2018 Academic Year. This research is a classroom action research, which took place in 2 cycles. The research subjects were students of class VIII. Data collection techniques using assignments and tests. Data were analyzed using descriptive analysis in percentage and qualitative data analysis with reference to the Minimum Mastery Criterion $(K K M=76)$ and Classical Mastery $(K K=85 \%)$ for science subjects in VIII grade at SMP Negeri 2 Kuta in the academic year 2017/2018. The results showed an increase in science learning outcomes, namely: the average value of learning outcomes and classical completeness before action were 71.1 and $62 \%$. In the first cycle the average learning outcomes in knowledge competence was 76.4 with a classical completeness of $68 \%$. The average student learning outcomes on skills commentary was 77.5 with a classical completeness of $62 \%$. In cycle II the science learning outcomes in knowledge competence were 82.6 with a classical accuracy of $94 \%$, the learning outcomes in the skills competence were 86.5 with a classical completeness of $100 \%$. Based on these results it can be concluded that the application of the problem posing learning model can improve the learning outcomes of students of class VIII A of SMP Negeri 2 Kuta in the even semester of the academic year $2017 / 2018$.

Keywords: Problem Posing Learning Model and Learning Outcomes 


\section{PENDAHULUAN}

Mata pelajaran Ilmu Pengetahuan Alam (IPA) di tingkat SMP adalah mata pelajaran yang wajib diberikan sebagai mata pelajaran integrative science. IPA atau Sains merupakan pengetahuan holistik. Oleh karena itu pembelajaran IPA harus diselenggarakan secara terpadu. Konsep keterpaduan ini telah dikembangkan pada Kompetensi Inti (KI) dan Kompenti Dasar (KD), yakni dalam satu KD telah memadukan konsep-konsep dasar biologi, fisika dan kimia. Perubahan ini tentu saja berdampak pada proses pembelajaran IPA, untuk itu diperlukan buku pedoman yang berorientasi pada terciptanya proses pembelajaran IPA terpadu. Namun demikian penerapan IPA terpadu belum sepenuhnya berjalan sesuai dengan amanat kurikulum 2013. Hal ini dapat diamati dari soal-soal ujian nasional atau tes untuk lomba lainnya, di mana soal-soal tersebut masih tersusun atas bidang ilmu biologi, fisika dan kimia secara parsial.

$\begin{array}{rrrr}\text { Kendala yang } & \text { dihadapi } & \text { siswa } \\ \text { dalam belajar IPA } & \text { adalah } & \text { pada }\end{array}$ pembahasan soal-soal materi fisika. Siswa hanya akan mampu mengerjakan soal yang sama dengan contoh soal yang diberikan oleh guru. Tetapi bila soalnya divariasikan, maka siswa akan merasa kesulitan dalam menyelesaikan soal tersebut. Seperti yang peneliti amati di kelas VIII A, yang mana kelas tersebut adalah kelas unggulan yang memiliki prestasi belajar pada bidang akademik yang cukup tinggi, sehingga kelas VIII A selalu ditunjuk untuk mewakili sekolah dalam ajang olimpiade atau lomba akademik lainnya. Namun demikian, hasil belajar IPA khususnya pada KD yang memuat materi fisika belum mencapai ketuntasan $85 \%$. Adapun hasil rata-rata ulangan harian siswa pada mata pelajaran IPA tahun pelajaran 2017/2018 dengan KKM 76 selengkapnya disajikan pada Tabel 1

Tabel 1. Persentase Ketuntasan Belajar IPA Kelas VIII A Tahun Pelajaran 2017/2018.

\begin{tabular}{|c|c|c|}
\hline No & Pokok Bahasan & $\begin{array}{l}\text { Persentase } \\
\text { Ketuntasan } \\
\end{array}$ \\
\hline 1 & $\begin{array}{l}\text { Gerak pada makhluk } \\
\text { Hidup }\end{array}$ & $88 \%$ \\
\hline 2 & $\begin{array}{l}\text { Gerak Lurus, Hukum } \\
\text { Newton tentang Gerak }\end{array}$ & $66 \%$ \\
\hline 3 & $\begin{array}{l}\text { Usaha dan Hukum } \\
\text { Tentang Gerak }\end{array}$ & $70 \%$ \\
\hline 4 & $\begin{array}{l}\text { Struktur } \\
\text { Tumbuhan } \\
\text { Fungsinya }\end{array}$ & $87 \%$ \\
\hline 5 & $\begin{array}{l}\text { Sistem Pencernaan pada } \\
\text { Manusia }\end{array}$ & $86 \%$ \\
\hline 6 & Sistem Peredaran darah & $87 \%$ \\
\hline 7 & Zat Aditif dan Adiktif & $89 \%$ \\
\hline 8 & Tekanan pada Zat & $65 \%$ \\
\hline
\end{tabular}

Melihat rendahnya hasil belajar IPA khususnya pada materi fisika, dimungkinkan karena kurangnya porsi waktu bagi siswa untuk melatih diri dalam menyelesaikan soal-soal yang lebih bervariasi. Mengingat watu yang tersedia dalam proses pembelajaran di kelas sangat terbatas dan siswa diharapkan trampil dalam menyelesaikan soal-soal fisika yang bervariasi, maka dari itu seorang guru perlu memilih model pembelajaran yang memberikan kesempatan kepada siswa untuk kreatif dalam menyelesaikan soalsoal yang bervariasi. Menurut (Satiadarma, M.P. \& Waruwu, 2003), kreativitas merupakan salah satu modal yang harus dimiliki siswa untuk mencapai prestasi belajar. Menurut Torrance, Getzels, Jakson, dan Yamamoto dalam (Munandar, 2014) menyatakan bahwa kelompok siswa yang kreativitasnya tinggi tidak berbeda dengan prestasi sekolah dari kelompok siswa yang intelegensinya relatif lebih 
tinggi. Untuk mengatasi kelemahan yang terjadi di kelas VIII A, maka peneliti sebagai guru di kelas VIII A mencoba menerapkan model pembelajaran problem posing pada materi Getaran, Gelombang, dan Bunyi.

Model pembelajaran problem posing mengharuskan siswa mengajukan soal atau masalah dari informasi yang diberikan (Amri, 2013). Menyusun soal atau mengajukan masalah merupakan pangkal semua kreasi. Orang yang memiliki kemampuan berkreasi dikatakan memiliki sikap kreatif. Selain itu dengan pengajuan soal, siswa diberi kesempatan aktif secara mental, fisik, dan sosial serta memberikan kesempatan kepada siswa untuk menyelidiki dan membuat jawaban. Problem Posing memberikan kelebihan pada siswa dalam hal memperoleh pengetahuan dengan cara menganalisis suatu masalah (Cankoy \& Darbas, 2011). Hal ini dapat dilihat dari tiga hal yaitu pengulangan masalah, visualisasi masalah dan penalaran kualitatif siswa. Melalui penerapan model problem posing dalam pembelajaran, diharapkan siswa mendapat kesempatan untuk mengembangkan kreasinya dalam menulis soal yang bervariasi dan kemampuannya dalam menyelesaiakan soal yang disusunnya.

Berdasarkan uraian di atas, peneliti mencoba menerapkan model pembelajaran problem posing untuk meningkatkan hasil belajar IPA siswa kelas VIII A pada semester genap tahun pelajaran 2017/2018.

\section{METODE PENELITIAN}

Jenis Penelitian
Secara umum tujuan penelitian ini adalah untuk meningkatkan hasil belajar IPA siswa kelas VIII A pada semester genap Tahun pelajaran 2017/2018. Sesuai dengan tujuan penelitian, rancangan yang digunakan dalam penelitian ini adalah penelitian tindakan kelas (classroom action research) (Sugiyono, 2010). Penelitian Tindakan Kelas pencermatan dalam bentuk tindakan terhadap kegiatan belajar yang sengaja dimunculkan dan terjadi dalam sebuah kelas secara bersamaan Penelitian tindakan kelas ini dilaksanakan di SMP Negeri 2 Kuta, seminyak, Kecamatan Kuta, Kabupaten Badung.

\section{Tempat dan waktu penelitian}

Penelitian ini dilaksanakan di SMP Negeri 2 Kuta pada semester genap (bulan Februari-bulan April 2018).

Subjek dalam penelitian ini adalah siswa kelas VIII A SMP Negeri 2 Kuta, dengan jumlah 34 siswa tahun pelajaran 2017/2018.

\section{Jenis Data}

Data dari penelitian ini adalah berupa: (1) data kompetensi pengetahuan yaitu data hasil belajar yang diperoleh dari hasil tes dan nilai tugas mandiri, (2) data kompetensi keterampilan diperoleh dari kreativitas siwa dalam penyusunan soal dan presentasi pemecahan soal dengan menggunakan lembar observasi, (3) data afektif diperoleh dari catatan guru mengenai sikap siswa selama proses pembelajaran.

\section{Rancangan Penelitian}

Penelitian ini dirancang dalam 2 siklus, yang terdiri dari beberapa tahapan 
yaitu: (1) perencanaan, (2) tindakan, (3) observasi, dan (4) refleksi dengan rincian sebagai berikut.

1) Tahap Perencanaan

Perencanaan terdiri atas: mengidentifikasi materi pokok yang akan diajarkan yaitu materi Getaran dan Gelombang, menyusun persiapan mengajar berupa Rencana Pelaksanaan Pembelajaran (RPP), menyusun instrumen penelitian yang berupa pedoman observasi kreativitas belajar, buku catatan observasi afektif, merancang alat bantu proses pembelajaran serta menyusun tes akhir siklus.

2) Tindakan (Acting)

Pelaksanaan tindakan penelitian merupakan tindak lanjut dari perencanaan. Secara sederhana terdapat beberapa prosedur yang dilaksanakan dalam melakukan tindakan yaitu: Melakukan pembelajaran berdasarkan langkahlangkah pembelajaran dengan model problem posing.

3) Observasi (Observing)

Hasil Observasi dalam penelitian ini menguraikan perkembangan proses pembelajaran, dan pengaruh dari tindakan yang dipilih terhadap kondisi kelas dalam bentuk data. Atau bisa dikatakan sebagai kegiatan merekam informasi dan dampak dari pelaksanaan tindakan baik dengan atau tanpa alat bantu. Data yang dihimpun melalui pengamatan (observasi) ini meliputi data kuantitatif dan data kualitatif sesuai dengan indikator-indikator yang telah ditetapkan.

4) Refleksi (Reflecting)

Refleksi merupakan langkah lanjut untuk mengevaluasi semua kegiatan dalam penelitian. Refleksi dilakukan berdasarkan hasil observasi untuk mendapat masukan, dari pelaksanaan model pembelajaran problem posing yang diterapkan untuk perbaikan mutu pendidikan. Pada tahap ini yang dilakukan adalah menganalisis hasil evaluasi observasi dalam usaha melihat hambatan-hambatan yang terjadi. Hasil refleksi akan digunakan sebagai bahan evaluasi siklus berikutnya

\section{Teknik Pengumpulan Data dan Analisis Data Hasil Belajar}

Data hasil belajar IPA siswa pada kompetensi keterampilan dikumpulkan melalui observasi dengan menggunakan format observasi kreatifitas dalam penyususnan soal dan presentasi hasil pembahasan soal. Data hasil pengamatan dianalisis secara deskriptif dengan mencari jumlah skor perolehan dari masing-masing siswa.

Data hasil belajar pada kompetensi pengetahuan dikumpulkan melalui hasil tugas mandiri dan tes akhir siklus. Hasil belajar untuk masing-masing siswa $\left(\mathrm{X}_{\mathrm{h}}\right)$ diperoleh dengan menggunakan persamaan berikut.

$$
\begin{aligned}
& X{ }_{h=i} \frac{\text { kuis }^{\prime}+2 T_{\mathrm{HB}}}{3} i \\
& X h=\frac{\text { rata }- \text { ratatugas }+(2 \times \text { test akhir siklus })}{3}
\end{aligned}
$$

Keterangan:

$\mathrm{Xh}=$ Hasil Belajar siswa

Rerata nilai hasil belajar diperoleh dengan

menggunakan persamaan: $\dot{X}_{h}=\frac{\sum X_{h}}{N}$

Keterangan

$$
\begin{aligned}
& \dot{X}_{h}=\text { rerata hasil belajar } \\
& \Sigma X_{h}=\text { jumlah nilai kognitif seluruh } \\
& \text { soal }
\end{aligned}
$$$$
N=\text { ¿ Jumlah seluruh siswa }
$$ 
Ketuntasan klasikal (KK) dihitung dengan rumus berikut:

$K K=\frac{\text { Jumlah } \text { siswa yang mendapat nilai }>76}{\text { jumlah seluruh } \text { siswa }} x$

\section{Indiktor Keberhasilan Tindakan}

Penerapan model pembelajaran problem posing pada kelas VIII A dikatakan berhasil apabila:

a. Adanya peningkatan rata-rata nilai hasil belajar (komptensi keterampilan dan pengetahuan) setiap siklusnya sekurang-kurangnya sama dengan KKM yaitu 76 .

b. Tingkat keberhasilan siswa secara klasikal mencapai $\geq 85 \%$ dari total jumlah siswa yang telah lulus KKM dengan nilai sekurang-kurangnya 76 .

\section{HASIL PENELITIAN}

Deskripsi hasil penelitian merupakan deskripsi proses pembelajaran IPA di kelas VIII A SMP Negeri 2 Kuta pada semester genap tahun pelajaran 2017/2018.

Pada siklus I, hasil belajar siswa pada kompetensi keterampilan diperoleh dari hasil observasi yang dilakukan pada pertemuan pertama dan kedua, yaitu pada saat pelaksanaan penyusunan soal, pembahasan soal dan presentasi dengan menggunakan lembar observasi penilaian. Hasil pengamatan dan analisis pada akhir siklus I menunjukkan rata-rata hasil belajar pada kompetensi keterampilan sebesar 77,5 dengan ketuntasan klasikal 62\%.

Data hasil belajar IPA pada kompetensi pengetahuan diperoleh melalui tugas mandiri dan hasil tes akhir siklus I. Berdasarkan hasil analisis diroleh rata-rata 76,4 dengan ketunsan klasikal 68\%. Jadi penelitian pada siklus I dikatakan belum memenuhi keberhasilan tindakan.
Pada siklus II, pelaksanaan tindakan dirancnag dalam 4 kali pertemuan dengan materi gelombang. Rata-rata hasil belajar IPA pada kompetensi keterampilan sebesar 86,5 dengan ketuntasan klasikal 100\%. Rata-rata hasil belajar IPA pada kompetensi pengetahuan sebesar 82,6 dengan ketuntasan klasikal sebesar 94\%. Jadi tindakan pada siklus II sudah memenuhi kreteria keberhasilan tindakan.

\section{PEMBAHASAN}

Hasil penelitian selama dua siklus menunjukkan terjadinya peningkatan hasil belajar siswa yang meliputi hasil belajar pada kompetensi pengetahuan dan keterampilan baik secara individu maupun klasikal. Peningkatan hasil belajar IPA terutamanya pada materi fisika siswa di kelas VIIIA disebabkan oleh model pembelajaran problem posing yang diterapkan selama ini. Kegiatan penyusunan soal, pembahasan soal, dan presentasi dalam model pembelajaran ini memberikan kontribusi dalam meningkatkan hasil belajar siswa. Langkah-langkah pembelajaran dalam model problem posing yang dilaksanakan di kelas VIIIA adalah sebagai berikut.

Pada kegiatan pendahuluan, guru menyampaikan indikator dan tujuan pembelajaran. Siswa akan lebih menghargai proses pembelajaran apabila telah mengetahui tujuan pembelajaran terlebih dahulu. Guru memberikan perhatian, motivasi, apersepsi, dan konsepsi awal yang jelas.

Langkah pertama yaitu penyampaian materi. Guru menyajikan informasi berupa garis besar materi kepada siswa dan memberikan kesempatan untuk bertanya apabila ada yang belum dimengerti. Memberikan contoh soal dan memberikan kesempatan kepada siswa 
untuk mengerjakan dengan bimbingan guru. Pada langkah ini, siswa harus benarbenar memberi perhatian penuh selama penyampaian materi karena dengan demikian akan sangat membantu mereka dalam menjawab soal yang diajukan oleh guru.

Langkah kedua yaitu penyusunan dan pengajuan soal. Soal yang disusun tidak boleh sama dengan contoh soal yang sudah dibahas. Melalui kegiatan penyusunan soal ini, siswa diberikan kesempangan mengembangkan kreativitasnya dalam pembelajaran. Tingkat kreativitas belajar memiliki keterkaitan dengan hasil belajar. Jika siswa memiliki kreativitas tinggi, maka siswa tersebut cenderung akan mempunyai rasa ingin tahu yang lebih besar untuk memahami segala permasalahan yang ada dalam pelajaran. Siswa cenderung rajin mencari informasi dalam mempelajari secara luas dan mendalam. Siswa akan dengan mudah menyerap, memahami dan mengolah segala informasi dalam pembelajaran dengan baik.

Langkah ketiga pertukaran soal. Pada langkah ini soal yang sudah selesai disusun ditukar dengan kelompok lain. Kegiatan ini bertujuan memberikan ruang lebih kepada siswa untuk mendapat kesempatan mengerjakan soal yang lebih bervariasi,

Langkah keempat yaitu diskusi kelompok dalam pembahasan soal dari kelompok lain. Kegitan ini bertujuan untuk menanamkan siswa berpikir kreatif dalam upaya mengembangkan pikirannya dalam pemecahan masalah dan menanamkan sikap menghargai pendapat orang lain.

Langkah kelima yaitu presentasi, pada kegiatan ini siswa dalam kelompok mempresentasikan jawaban mereka di depan kelas dan kelompok lain sebagai pemilik soal diberikan kesempatan menanggapi. Selama kegiatan presentasi dilaksanakan guru juga melakukan klarifikasi terhadap beberapa penjelasan siswa yang kurang sesuai agar siswa mampu menemukan kembali informasi yang hilang atau mengganti informasi yang salah dengan yang baru.

Langkah ke 6 yaitu pemberian tugas mandiri, pada kegiatan ini guru memberi tugas membuat soal dan pembahsannya. Kegiatan pemberian tugas menyusun soal membuat siswa akan berpikir kreatif. Karena soal yang disusun tiidak boleh sama dengan contoh soal yang sudah pernah diajukan. Disamping itu soal yang sudah disusun harus dijawab, hal ini akan membuat siswa berpikir kritis dan kreatif.

Berdasarkan uraian tersebut, model pembelajaran problem posing mampu memberikan ruang kepada siswa untuk berpikir kritis dan kreatif dalam pembelajaran yang pada akhirnya dapat meningkatkan hasil belajar. Problem posing memberikan kelebihan pada siswa dalam hal memperoleh pengetahuan dengan cara menganalisis suatu masalah (Cankoy \& Darbas, 2011). Hal ini dapat dilihat dari adanya langkah penyusunan soal, pertukaran soal dan pembahasan soal serta presentasi hasil jawaban, keempat kegiatan tersebut menuntut siswa untuk berpikir kreatif dan berpikir tingkat tinggi.Tujuan utama model pembelajaran problem posing adalah meningkatkan kreativitas belajar siswa dan pada akhirnya mampu meningkatkan hasil belajar.

Hasil penelitian yang diperoleh juga sejalan dengan penelitian yang dilakukan oleh Ai Sriwenda $\mathrm{R}$, yang memberikan bukti meyakinkan mengenai keefektifan dan keberhasilan model pembelajaran Problem Posing dapat 
meningkatkan kreativitas dan prestasi belajar siswa. Berdasarkan uraian tersebut, terbukti secara teoretis dan empiris bahwa model pembelajaran problem posing cocok diterapkan dalam pembelajaran IPA pada materi fisika untuk meningkatkan hasil belajar IPA.

Peningkatan hasil belajar IPA siswa yang terjadi selain disebabkan karena penerapan model pembelajaran problem posing, juga disebabkan karena upaya-upaya yang dilakukan untuk memperbaiki hasil dengan memperhatikan kendala-kendala dan kekurangan yang terjadi pada siklus I. Hasil penelitian dan refleksi pada siklus I selanjutnya digunakan sebagai acuan dalam menerapkan model pembelajaran problem posing pada siklus II sehingga kendalakendala yang terjadi pada siklus I dapat dikurangi dan kegiatan pembelajaran menjadi lebih optimal.

Upaya-upaya dilakukan dengan mengoptimalkan dan memantapkan setiap langkah pembelajaran agar hasil belajar siswa lebih meningkat. Upaya-upaya tersebut yaitu: 1) Guru memberikan bimbingan dan lebih menekankan mengenai cara bagaimana menyelesaikan suatu masalah atau soal, pertama dibaca terlebih dahulu soal tersebut dengan baik dan cermat agar siswa memahami masalah yang ada pada soal tersebut, kemudian menulis apa yang diketahui dari soal, apa yang ditanyakan, setelah itu siswa akan mengetahui cara pemecahan masalah pada soal tersebut. Terakhir penerapan matematika, disini siswa dituntut memiliki kemampuan matematika sederhana yang unggul. 2) Guru memberikan pengertian tentang rasa memiliki antar kelompok, lebih mengawasi siswa yang kurang disiplin, memberikan arahan bahwa tugas kelompok akan dinilai dan merupakan hasil dari kerjasama kelompok, sehingga setiap siswa harus ikut berperan dalam melaksanakan tugas kelompok. 3) Alokasi waktu untuk setiap langkah diatur lebih proporsional agar waktu yang tersedia selama $5 \times 40$ menit dapat dimanfaatkan dengan baik dan tidak mengalami kekurangan waktu khususnya pada langkah penyusunan dan pembahasan soal. 4) Guru lebih menyemangati siswa yang lemah agar nilai hasil belajar IPA siswa meningkat di siklus II. 5) Guru melakukan refleksi diri dengan menanyakan kepada siswa kekurangan penerapan model pembelajaran Problem Posing

Pada siklus II, siswa kelas VIIIA telah mampu beradaptasi dan terbiasa dengan langkah-langkah model pembelajaran problem posing sehingga memudahkan dalam mencapai peningkatan hasil belajar siswa. Siswa mulai terbiasa menyususn soal, bertanya, berdiskusi, dan presentasi. Siswa telah mampu bertanggungjawab dan telah mengenal siswa lainnya serta terbiasa bekerja pada kelompoknya. Hasil tugas mandiri yang menunjukkan evaluasi harian siswa menampakkan nilai yang memuaskan karena siswa telah memanfaatkan proses pembelajaran dengan baik dan mulai terbiasa diberikan tugas mandiri.

Berdasarkan hasil penelitian yang dilaksanakan dalam dua siklus di kelas VIIIA SMP Negeri 2 Kuta pada semester genaptahun pelajaran 2017/2018 untuk topik Getaran dan Gelombang ditemukan bahwa nilai rata-rata kompetensi pengetahuan IPA pada siklus I adalah 76,4 dengan ketuntasana klasikal 68\%, dan hasil analisis kompetensi keterampilan siswa menunjukkan angka 77,5 dengan ketuntasan klasikal 62\%. Sehingga tindakan pada siklus I dikatakan belum berhasil, karena kreteria keberhasilan 
tindakan dalam penelitian ini adalah dengan ketuntasan klasikal 85\%

Berdasarkan refleksi siklus I, maka diadakan perbaikan sehingga pada siklus II diperoleh adanya peningkatan hasil belajar IPA. Berdasarkan analisis data pada siklus II, ditemukan bahwa perolehan skor ratarata hasil belajar IPA pada kompetensi pengetahuan 82,6 dengan ketuntasan klasikal 94\% dan pada kompetnsi keterampilan dengan nilai 86,5 dengan ketuntasan klasikal 100\%. Jadi pada siklus II penerapan model pembelajaran problem posing dikatakan berhasil meningkatkan hasil belajar IPA kelas VIIIA SMP Negeri 2 Kuta pada semester genap tahun pelajaran 2017/2018.

Berdasarkan analisis data tindakan model pembelajaran problem posing pada siklus I, dan siklus II untuk hasil belajar IPA pada kompetensi pengetahuan dan kompetensi keterampilan dapat digambarkan dalam sebuah diagram sebagai berikut.

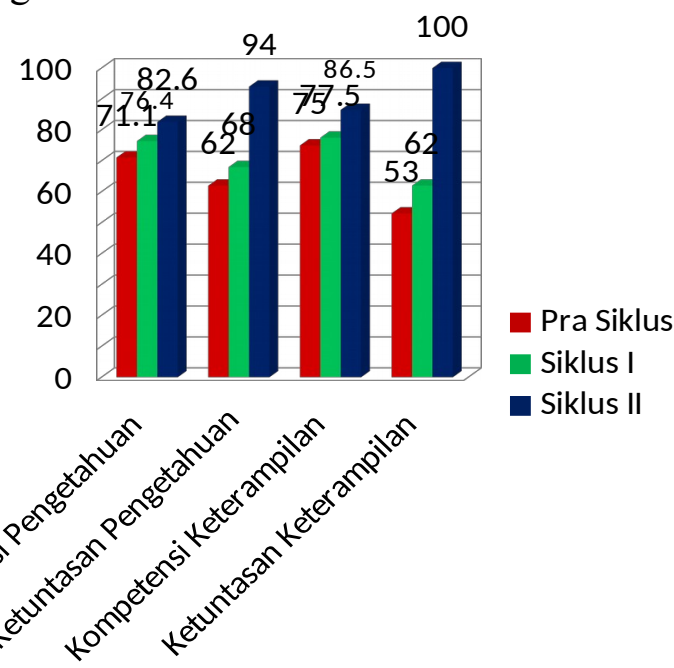

Gambar 01. Hasil Belajar IPA Pada Kompetensi Pengetahuan Dan Kompetensi Keterampilan

\section{Simpulan}

Berdasrakan hasil penelitian dan pembahasan yang telah diuraikan pada bab sebelumnya, maka dapat disimpulkan bahwa, penerapan model pembelajaran problem posing dapat meningkatkan hasil belajar IPA siswa kelas VIIIA SMP Negeri 2 Kuta pada semester genap tahun pelajaran 2017/2018. Hal ini dapat dibuktikan, dimana pada pra siklus (sebelum tindakan) rata-rata hasil belajar IPA pada kompetensi pengetahuan $=71,1$ dengan ketuntasan klasikal 62\%, pada kompetensi keterampilan $=75,0$ dengan ketuntasan klasikal 53\%. Hasil penelitian pada siklus I diperoleh rata-rata hasil belajar IPA pada kompetensi pengetahuan $=76,4$ dengan ketuntasan klasikal $=68 \%$ dan nilai kompetensi keterampilan $=77,5$ dengan ketuntasan klasikal $=62 \%$. Hasil penelitian pada siklus II diperoleh rata-rata nilai kompetensi pengetahuan $=82,6$ dengan ketuntasan klasikal 94\% dan nilai rata-rata kompetensi keterampilan $=86,5$ ketuntasan klasikal 100\%. Pada siklus II kriteria keberhasilan penelitan ini telah tercapai. Nilai rata-rata hasil belajar siswa mengalami peningkatan dari siklus I ke siklus II. Jadi dapat disimpulkan bahwa pembelajaran dengan model Problem Posing yang diterapkan pada kelas VIIIA SMP Negeri 2 Kuta pada semester genap tahun pelajaran 2017/2018 dalam pokok bahasan getaran dan gelombang dapat meningkatkan hasil belajarnya.

\section{Saran}

Berdasarkan hasil penelitian dan pembahasan yang telah dipaparkan serta temuan-temuan yang diperoleh dalam penelitian ini, maka dapat diajukan saran sebagai berikut.

\section{Bagi Guru}

1) Implementasi model pembelajaran problem posing sangat baik digunakan sebagai role model pembelajaran di 
dalam meningkatkan hasil belajar. Sehingga peneliti menyarankan untuk mencoba menerapkan model pembelajaran problem posing pada pembelajaran IPA pada pokok bahasan lain.

2) Guru hendaknya mengatur waktu lebih efektif apabila nantinya menerapkan model pembelajaran problem posing di kelas sehingga semua langkahlangkahnya dapat berjalan dengan baik

\section{Bagi Sekolah}

Sekolah dapat menjadikan model pembelajaran problem posing role model pembelajaran inovatif dalam, sehingga menyebabkan proses belajar mengajar menjadi I2M3.

\section{Bagi Siswa}

Siswa diharapkan memanfaatkan waktu untuk belajar di sekolah dengan baik, terlebih lagi guru telah menerapkan model pembelajaran yang inovatif yang sesuai dengan kemampuan siswa dan telah difasilitasi dengan suasana belajar yang bebas dan menyenangkan. Siswa diharapkan mengikuti pelajaran dengan sungguh-sungguh agar memperoleh nilai yang maksimal.

\section{DAFTAR PUSTAKA}

Amri, S. (2013). Pengembangan \& Model Pembelajaran Dalam Kurikulum. Prestasi Pustakarya.

Cankoy \& Darbas. (2011). Effect Of A Problem Posing Based Problem.

Munandar, U. (2014). Pengembangan Kreativitas Anak Berbakat. Rineka Cipta.

Satiadarma, M.P. \& Waruwu, F. E. (2003). Mendidik Kecerdasan. Pustaka
Populer Obor.

Sugiyono. (2010). Metode Penelitian Kuantitatif Kualitatif dan $R \& D$.

Alphabeta. 